\title{
Review
}

\section{Photocatalytic treatment technology for palm oil mill effluent (POME) - A review}

\author{
Mohammed Haji Alhaji ${ }^{a, b}$, Khairuddin Sanaullah ${ }^{b, *}$, Soh-Fong Lim ${ }^{b}$, \\ Afrasyab Khan ${ }^{b}$, Cirilo N. Hipolito ${ }^{b}$, Mohammad O. Abdullah ${ }^{b}$, \\ Showkat A. Bhawani ${ }^{c}$, Tahir Jamil ${ }^{d}$ \\ a Nigeria Institute of Leather and Science Technology, Zaria, Nigeria \\ $\mathrm{b}$ Department of Chemical Engineering and Energy Sustainability, Faculty of Engineering, Universiti Malaysia \\ Sarawak (UNIMAS), Malaysia \\ c Department of Chemistry, Faculty of Resource Science and Technology, Universiti Malaysia Sarawak (UNIMAS), \\ Malaysia \\ d Institute of Chemical Engineering and Technology, The Punjab University, Lahore, Pakistan
}

\section{A R T I C L E I N F O}

\section{Article history:}

Received 29 February 2016

Received in revised form 29 April

2016

Accepted 6 May 2016

Available online 3 June 2016

Keywords:

Photocatalytic degradation

Palm oil mill effluent

Treatment techniques

Photocatalysis

Titanium-dioxide

Reactor configuration

\begin{abstract}
A B S T R A C T
This review provides insight into various techniques utilized for the treatments of palm oil mill effluents (POME). Generally, POME treatment is achieved in two ways, these are (1) pretreatment stages, involving majorly the reduction of oil and grease and suspended matter and (2) an advanced treatment stage, in which wastewater contaminants (e.g. BOD, $\mathrm{COD}$ ) are reduced to standard discharge limits. Different methods utilized in the treatment of POME such as coagulation-flocculation, anaerobic, aerobic and membrane technology are explained fully and recent trends in their advancement and improvement are outlined. Though, various pilot or industrial scale treatment plants have been reported in scientific literature for POME treatments methods such as anaerobic, aerobic and membrane technology, the literature is still scarce for application of photocatalytic degradation technology to POME treatment as the technology is still in development stage and has not been fully utilized on an industrial scale in palm oil mill industries. This is mainly as a result of inadequate investigation involving POME degradation. The review presented here is focused on photocatalytic degradation technology and reflects published outcomes with the aim of offering the technique as an attractive and sustainable process units. Also the potential of the process to replace some of the well-known separation and degradation technologies has been highlighted at advanced treatment stage for POME.
\end{abstract}

( 2016 Institution of Chemical Engineers. Published by Elsevier B.V. All rights reserved.

\section{Contents}

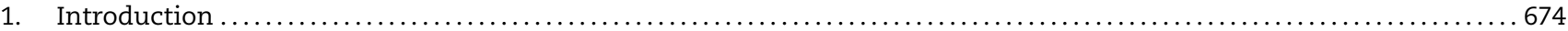

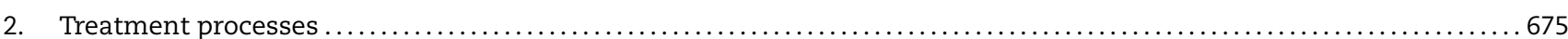

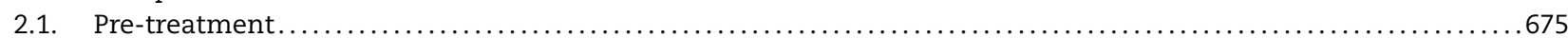

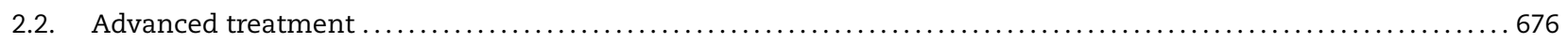

\footnotetext{
* Corresponding author. Tel.: +60 168619960.

E-mail address: skhairuddin@unimas.my (K. Sanaullah).

http://dx.doi.org/10.1016/j.psep.2016.05.020

0957-5820/@ 2016 Institution of Chemical Engineers. Published by Elsevier B.V. All rights reserved.
} 